\title{
THE USE OF CYCLOSPORINE MODIFIES THE CLINICAL AND HISTOPATHOLOGICAL PRESENTATION OF TUBERCULOSIS AFTER RENAL TRANSPLANTATION
}

Eloir BIZ, Carlos Alberto Pires PEREIRA, Luis Antonio Ribeiro de MOURA, Ricardo SESSO, Maria Lucia dos Santos VAZ, Alvaro Pacheco SILVA FILHO \& José Osmar Medina PESTANA

\begin{abstract}
SUMMARY
Tuberculosis is one of the most frequent opportunistic infections after renal transplantation and occurred in 30 of 1264 patients transplanted between 1976 and 1996 at Hospital São Paulo - UNIFESP and Hospital Dom Silvério, Brazil. The incidence of 2.4\% is five times higher than the Brazilian general population. The disease occurred between 50 days to 18 years after the transplant, and had an earlier and worse development in patients receiving azathioprine, prednisone and cyclosporine, with 35\% presenting as a disseminated disease, while all patients receiving azathioprine and prednisone had exclusively pulmonary disease. Ninety percent of those patients had fever as the major initial clinical manifestation. Diagnosis was made by biopsy of the lesion (50\%), positivity to M. tuberculosis in the sputum (30\%) and spinal cerebral fluid analysis (7\%). Duration of treatment ranged from 6 to 13 months and hepatotoxicity occurred in 3 patients. The patients who died had a significant greater number of rejection episodes and received higher doses of corticosteroid. In conclusion, the administration of cyclosporine changed the clinical and histopathological pattern of tuberculosis occurring after renal transplantation.
\end{abstract}

KEYWORDS: Tuberculosis; Renal transplantation; Cyclosporine; Steroids.

\section{INTRODUCTION}

Infection is a frequent complication and one of the main causes of death in patients submitted to renal transplantation, even when considering the greater availability of diagnostic techniques and the increased efficacy of antimicrobial agents ${ }^{29}$. This high frequency of infection is associated with the immunosuppressive therapy used in patients who are previously immunocompromised ${ }^{28,36}$. In this situation, the incidence of tuberculosis (TB) is 0.5 to $1 \%$ in the United States and 1 to $4 \%$ in Europe, and can reach about $10 \%$ in underdeveloped/ developing countries such as India ${ }^{32,33}$.

Atypical clinical manifestations of TB are more often found in these groups of patients ${ }^{6,8,9,23,38,40}$ and the results are conflicting regarding the diagnostic value of the cutaneous test (PPD) ${ }^{39}$. The use of chemotherapy immediately after transplantation is questioned and the impact of TB and of antituberculosis drugs on the patient and graft survival has not been established ${ }^{1}$. Therefore, we studied the incidence of TB in 1264 renal transplant recipients and analyzed the clinical manifestations and the diagnostic methods used.

\section{MATERIAL AND METHODS}

A retrospective analysis of 1264 renal transplants was carried out at the Renal Transplant Unit of Hospital São Paulo, UNIFESP, and of
Hospital Dom Silvério Gomes Pimenta, São Paulo, during the period from June 1976 to March 1996. There were no exclusion criteria and all renal transplants performed during this period were considered eligible for the study. Tuberculosis was diagnosed in 30 of the 1264 transplant patients, with 22 receiving a graft from a living related and 8 from cadaveric donors. Seventeen patients received the renal graft from living haploidentical donors, 4 patients from an HLA identical donor and one from an HLA-distinct donor. The patients who received the transplant from cadaver donors were selected according to blood ABO compatibility, negative cross-match against HLA antigens and order of enrollment in the renal transplant program. The living donors were selected among family members based on ABO compatibility, HLA compatibility and negative cross-match against HLA antigens.

The diagnosis of TB was based on the following criteria: demonstration of alcohol acid-resistant bacilli (AARB) by bacterioscopy or microbial growth in culture, demonstration of caseous granuloma upon histopathological examination indicated by the presence of AARB, adenosine deaminase levels in the cerebrospinal fluid higher than $40 \mathrm{U} / \mathrm{L}$ or in the pleural effusion determined by the calorimetric method of Giusti ${ }^{38}$.

Tuberculosis was classified, according to the site of isolation of Mycobacterium tuberculosis, into pulmonary TB when the bacterium was isolated from sputum and bronchial lavage, and extrapulmonary, when the bacterium was isolated from other tissues. 


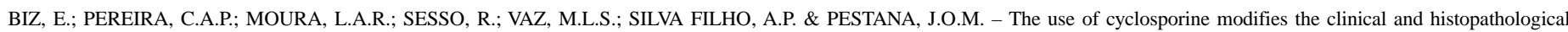
presentation of tuberculosis after renal transplantation. Rev. Inst. Med. trop. S. Paulo, 42(4): 225-230, 2000.

Immunosuppression consisted of a double therapy (azathioprine and prednisone) for patients transplanted up to 1986. From then on, cyclosporine was introduced and a triple therapy (azathioprine, prednisone and cyclosporine) was established. The initial dose of prednisone was 1.5 to $2 \mathrm{mg} / \mathrm{kg} /$ day and was then progressively reduced to $0.2 \mathrm{mg} / \mathrm{kg} /$ day on the 6th month. Azathioprine was administered at a dose of 1 to $2 \mathrm{mg} / \mathrm{kg} / \mathrm{day}$, being adjusted according to total leukocyte count. The initial cyclosporine A dose was 6 to $8 \mathrm{mg} / \mathrm{kg} /$ day, starting on the first post-transplant day, and adjusted to maintain its trough blood level between 100 and $250 \mathrm{ng} / \mathrm{dL}$.

All patients with TB were initially treated using a combination of isoniazid $(10 \mathrm{mg} / \mathrm{kg})$, rifampicin $(10 \mathrm{mg} / \mathrm{kg})$ and pirazinamide $(30 \mathrm{mg} /$ $\mathrm{kg}$ ), and subsequent combination with other drugs, when necessary. Pirazinamide was used only for the first 2 months of treatment while isoniazid and rifampicin were administered for 6 to 13 months. Hepatic function was monitored in all patients and hepatotoxicity was diagnosed when the alanine aminotransferase level increased four times, compared to the upper normal limit. Two patients had previously received isoniazid chemoprophylaxis.

The Student t-test was used for comparing continuous variables and $\mathrm{p}<0.05$ was set as the level of significance.

\section{RESULTS}

Tuberculosis was diagnosed in 30 patients (2.4\%). Table 1 shows the demographic and clinical characteristics of the patients. Mean age was 33 years, ranging from 16 to 60 years. Twenty-one patients were males, 22 were white and 8 black. Mean weight was $52.7 \mathrm{~kg}$ and mean height $162 \mathrm{~cm}$. The most frequent etiology of chronic renal insufficiency was chronic glomerulonephritis (70\%). Mean time of dialysis was 32.2 months, ranging from 9 to 79 months. Twenty-six patients $(86.7 \%)$ were on hemodialysis, $3(10 \%)$ received continuous ambulatory peritoneal dialysis and one patient was on conservative treatment. Fifteen patients (50\%) belonged to blood group type A, seven (23.3\%) to group O, six (20\%) to group B and two $(6.7 \%)$ to group AB. Only one patient had received a second renal transplant.

The initial signs and symptoms of the disease are summarized in Table 2. Fever was the most frequently observed sign (90\%), being generally intermittent and of low degree. Other common symptoms were weight loss $(70 \%)$, cough $(66.6 \%)$, profuse sweating $(26.6 \%)$ and anorexia (20\%). The lung was involved in 18 patients (60\%). In 17 cases $(57 \%)$ there was isolated lung involvement, in another case pleuropulmonary involvement was observed. Isolated pleural involvement occurred in 2 patients $(7 \%)$, and in 4 cases other isolated sites were found to be affected (10\%). Disseminated TB was observed in 6 cases $(20 \%)$. Radiological chest findings are shown in Table 3.

No extrapulmonary TB was observed in patients receiving the double immunosuppression scheme, whereas the disseminated form was observed in $6 / 17(35 \%)$ patients whose drug regimen included cyclosporine A (Table 4).

TB was diagnosed between 50 days and 18 years after transplantation, with four patients $(13.3 \%)$ being diagnosed during the first 6 months after transplant, four (13.3\%) during the following 6 months, five (16.6\%)
Table 1

Demographic, clinical and laboratory characteristics of the 30 patients with TB

\begin{tabular}{ll}
\hline $\begin{array}{l}\text { Number of patients } \\
\text { Mean age (years) } \\
\text { Gender, N (\%) }\end{array}$ & 30 \\
$\quad$ Male & $21(16-60)$ \\
$\quad$ Female & $09(30)$ \\
Race, N (\%) & $22(73.3)$ \\
$\quad$ White & $08(26.7)$ \\
$\quad$ Black & $52.7( \pm 11.2)$ \\
Weight $(\mathrm{kg})$ & $162( \pm 0.04)$ \\
Height (cm) & \\
Cause of renal failure, N (\%) & $21(70.0)$ \\
$\quad$ Chronic glomerulonephritis & $02(6.6)$ \\
$\quad$ Systemic arterial hypertension & $02(6.6)$ \\
$\quad$ Not determined & $01(3.3)$ \\
$\quad$ Diabetes & $04(13.3)$ \\
$\quad$ Other & $32.2(9-79)$ \\
Mean time on dialysis (months) & $48.3(50$ days -103 months $)$ \\
Mean follow-up time (months) & $29(96.6)$ \\
First transplant, N (\%) & $2.43( \pm 1.61)$ \\
Serum creatinine, mg/dl & $3.65( \pm 0.04)$ \\
Serum albumin, g/dl &
\end{tabular}

Table 2

Signs and symptoms at the time when presenting with TB

\begin{tabular}{lrr}
\hline & N & \% \\
\hline Fever & 27 & 90.0 \\
Weight loss & 21 & 70.0 \\
Cough & 20 & 66.6 \\
Sudoresis & 8 & 26.6 \\
Anorexia & 6 & 20.0 \\
Acute respiratory insufficiency & 4 & 13.3 \\
Lumbar pain & 4 & 13.3 \\
Chest pain & 2 & 6.6 \\
Cervical mass & 2 & 6.6 \\
Headache & 2 & 6.6 \\
Hoarseness & 1 & 3.3 \\
Ascites & 1 & 3.3 \\
\hline
\end{tabular}

Table 3

Radiologic findings of the chest in 26 patients with pleuropulmonary or disseminated TB

\begin{tabular}{lcr}
\hline Chest X-ray pattern & $\mathrm{N}$ & $\%$ \\
\hline Pulmonary infiltration & 12 & 46.1 \\
Pulmonary cavitation & 06 & 23.0 \\
Pulmonary condensation & 04 & 15.3 \\
Pleural hemorrhage & 02 & 7.7 \\
Pulmonary infiltration and pleural hemorrhage & 01 & 3.8 \\
Increased mediastinum & 01 & 3.8 \\
\hline
\end{tabular}


during the second year, and the remaining 17 cases after this period.

In patients receiving prednisone and azathioprine the manifestations of TB occurred at a later time. Of the 13 patients receiving the double scheme, the disease manifested in 11 after the first 3 transplant years $(84.6 \%)$. In contrast, among the 17 patients using the triple immunosuppression scheme, TB occurred in $14(82.3 \%)$ during the first 3 years of transplantation, with the disease being observed in $7(41.1 \%)$ during the first year.

Primary extrapulmonary involvement occurred in one case before the end of the first year, and in 9 after the first transplant year. Three cases of disseminated TB were observed during the first transplant year.

In nine patients (30\%) the diagnosis was established by direct staining of the bacillus in the sputum, and in two by microscopic examination of cerebrospinal fluid (CSF) smears. Nineteen patients were diagnosed by biopsy of the affected organs, with 10 cases being diagnosed by transbronchial biopsy, one of them together with cervical ganglion biopsy, three by pleural biopsy, one by biopsy of the pericardium and another by biopsy of the cervical ganglion. In four patients TB was diagnosed at autopsy (Table 5).

The 19 biopsy cases were classified into three histological forms (Table 6): (a) "exudative" (four cases) characterized by a polymorphonuclear neutrophilic exudate, rupture of the basic tissue pattern with necrosis and a high amount of AARB; (b) "granulomatous" (three cases) characterized by the presence of typical tuberculous granulomas of the epithelioid form with occasional necrosis, giant cells and AARB, and (c) "mixed" (two cases) characterized by the presence of a neutrophilic exudate similar to that observed with the exudative form, and initial formation of epithelioid granulomas containing AARB. The exudative and mixed forms were associated with a poor clinical picture and were only observed when TB occurred during the first posttransplant year. The granulomatous form was mainly observed after the first post-transplant year. Of the 7 patients who died, four presented the granulomatous form, two the exudative form and two the mixed form.

Specific TB therapy consisted of different combinations of drugs, with isoniazid and rifampicin being used initially in all patients. The other drugs

\section{Table 4}

Tissues affected by TB in the total group of patients and in the groups receiving the double (azathioprine and prednisone) or triple (azathioprine, prednisone and cyclosporine) immunosuppression scheme

\begin{tabular}{llll}
\hline Localization & $\begin{array}{l}\text { Double scheme } \\
\text { N }(\%)\end{array}$ & $\begin{array}{l}\text { Triple scheme } \\
\text { N }(\%)\end{array}$ & $\begin{array}{l}\text { Total } \\
\text { N }(\%)\end{array}$ \\
\hline Lung & $10(77)$ & $07(41)$ & $17(57)$ \\
Pleura & $02(15)$ & $01(06)$ & $03(10)$ \\
Extrapulmonary & $01(08)$ & $03(18)$ & $04(13)$ \\
Disseminated & - & $06(35)$ & $06(20)$ \\
TOTAL & 13 & 17 & 30 \\
\hline
\end{tabular}

Table 5

Method of TB diagnosis in the 30 cases studied

\section{MICROSCOPIC:}

AARB in sputum

Cerebrospinal fluid analysis

HISTOLOGIC:

Tracheobronchial biopsy 10

Pleural biopsy 03

Tracheobronchial + ganglion biopsy $\quad 01$

Pericardium biopsy 01

Autopsy

Table 6

Post-transplant year of TB diagnosis, immunosuppression scheme and histological presentation of 19 patients submitted to biopsy

\begin{tabular}{|c|c|c|c|c|}
\hline \multirow{3}{*}{$\begin{array}{l}\text { TIME AFTER } \\
\text { TRANSPLANT }\end{array}$} & \multicolumn{4}{|c|}{ IMMUNOSUPPRESSION SCHEME } \\
\hline & \multicolumn{2}{|c|}{$\mathrm{AZA+PRED}$} & \multicolumn{2}{|c|}{$\mathrm{AZA+PRED+CYA}$} \\
\hline & $\mathrm{N}(\%)$ & HISTOLOGY & $\mathrm{N}(\%)$ & HISTOLOGY \\
\hline \multirow[t]{3}{*}{ 1st year } & $1(3)$ & 1 exudative & $7(23)$ & 1 granulomatous \\
\hline & & & 3 exud & \\
\hline & & & 2 mixe & \\
\hline 2nd year & $2(6)$ & & $4(13)$ & 3 granulomatous \\
\hline 3rd year & $3(10)$ & 1 granulomatous & $3(10)$ & 1 granulomatous \\
\hline 4th year & 0 & & $1(3)$ & \\
\hline 5 th year & $1(3)$ & 1 granulomatous & 0 & \\
\hline 6 th year & $2(6)$ & 1 granulomatous & $1(3)$ & 1 granulomatous \\
\hline 7 th year & 0 & & 0 & \\
\hline 8th year & $1(3)$ & 1 granulomatous & 0 & \\
\hline 9th year & $1(3)$ & 1 granulomatous & $1(3)$ & 1 granulomatous \\
\hline 10th year & $3(10)$ & 1 granulomatous & 0 & \\
\hline
\end{tabular}

Abbreviations: $\mathrm{AZA}=$ azathioprine; $\mathrm{PRED}=$ prednisone; $\mathrm{CYA}=$ cyclosporine. 


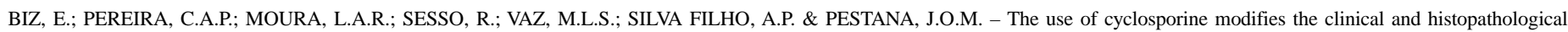
presentation of tuberculosis after renal transplantation. Rev. Inst. Med. trop. S. Paulo, 42(4): 225-230, 2000.

used were pirazinamide, ethambutol, streptomycin, ofloxacin, cyprofloxacin and azithromycin. Five patients showed an acute rejection episode after the beginning of therapy, three of whom did not recover renal function and returned to the dialysis program. Four of these patients used cyclosporine and three presented serum levels below $100 \mathrm{ng} / \mathrm{dL}$, with a mean value of $91.75 \pm 69.24 \mathrm{ng} / \mathrm{dL}$, which was significantly lower $(p<0.05)$ than that observed for patients who were cured of TB and who maintained adequate renal function $(162.16 \pm 139.70 \mathrm{ng} / \mathrm{dL})$. Two other patients received three different drug combinations due to hepatotoxicity and/or drug intolerance. The side effects observed were hepatotoxicity (2 cases), peripheral neuropathy ( 2 cases), hepatitis and neuropathy (1 case), gastritis, retrobulbar neuritis and labyrinthitis (1 case), and gout (1 case).

Of the 26 patients treated, $22(84 \%)$ were cured, with treatment duration ranging from 6 to 13 months. Three patients died during treatment and one patient stopped treatment. No recurrence of the disease was observed in any case (Table 7).

Although the doses of azathioprine and cyclosporine were higher in the group of patients who died, they were not significantly different from those for the group of cured patients. However, the mean prednisone dose and the number of acute rejection episodes were significantly higher in the group of patients who died (Table 8).

\section{DISCUSSION}

The incidence of TB in patients with chronic renal insufficiency who receive renal transplant is higher than that observed for the general population, ranging from 0.5 to $1 \%$ in the United States, from 1 to $4 \%$ in Europe, being $3.5 \%$ in Saudi Arabia and ranging from 5.7 to $11.8 \%$ in India $^{2,11}$. This difference between continents reflects the variation in the incidence of TB in the respective general populations. We observed TB

Table 7

Evolution of the 30 patients with TB diagnosis after renal transplantation

\begin{tabular}{llr}
\hline Evolution & $\mathrm{N}$ & $\%$ \\
\hline Cured after treatment - continue with functional graft & 17 & 56.7 \\
Cured after treatment - acute rejection and return & & \\
to chronic dialysis & 03 & 10.0 \\
Cured after treatment - acute rejection controlled & 02 & 6.6 \\
Died during treatment & 03 & 10.0 \\
Died without treatment - diagnosis at autopsy & 04 & 13.3 \\
Left medical follow-up & 01 & 3.3 \\
\hline
\end{tabular}

in $2.4 \%$ of transplanted patients, a rate 5 times higher than the prevalence in the general Brazilian population which is estimated to be $0.5 \%{ }^{25,30}$.

Immunosuppression is the main factor predisposing to infection in transplant patients, however, it has not yet been established which drugs result in a higher risk $^{27}$. SAHN \& LAKSHMINARAYAN reported reactivation of the disease in patients receiving high steroid doses ${ }^{17,31}$, and MILLAR \& HORNE observed more severe forms of TB in patients receiving more than $10 \mathrm{mg} /$ day of prednisone ${ }^{21}$. It was also shown that azathioprine causes dissemination of TB in experimental animals ${ }^{24}$. Two studies $^{13,26}$ did not report any relation between the incidence of mycobacterial infection and the use of cyclosporine as adjuvant in immunosuppression.

Among the studied patients diagnosed with TB, the oral prednisone dose and the number of treated rejection episodes were higher in those who died than in those who were cured. These results support the idea that the corticosteroid dose is related to the reactivation and severity of TB after renal transplantation ${ }^{31}$. TB was diagnosed in most of our patients $(63.3 \%)$ during the first three years after the transplant, with $42 \%$ being diagnosed during the first year, a period during which the steroid dose was higher. The cases that occurred earlier tended to be more severe and had a higher mortality, which is in agreement with data reported previously by other authors ${ }^{1,22}$. It is tempting to propose that, during this period, the immunosuppressive effect of previous uremia is still present, increasing the predisposition to infections $s^{3,4,12,15,24}$. Of the five patients showing acute rejection during TB treatment, 4 presented blood cyclosporine levels lower than $100 \mathrm{ng} / \mathrm{dL}$, corresponding to $50 \%$ of the level observed in patients without any alteration of graft function. This observation may explain the difficulties in finding the ideal dose for immunosuppression in order to prevent rejection and to minimize predisposition to opportunistic infections.

The histological pattern of the exudative form was observed during the first months after transplantation and was found to be associated with a poor prognosis. The granulomatous form showed a clinical picture similar to that found in non-immunosuppressed patients and occurred mainly after the first year of transplantation. One may speculate that high doses of corticosteroids play an important role in the presentation of the exudative form, preventing the organization of granulomas ${ }^{18,37}$.

Fever was a predominant symptom and TB should be suspected in all transplant patients who present fever of not readily definable etiology, especially when the lung is affected. The AARB test employed in the affected system led to the diagnosis of 9 of the 30 patients. Bronchoscopy, a more aggressive approach, enabled the diagnosis of 11 patients.

\section{Table 8}

Dose of immunosuppressive drugs and number of acute rejection episodes in patients with a diagnosis of TB who died compared to those who were cured

\begin{tabular}{lllll}
\hline & $\begin{array}{l}\text { Azathioprine } \\
(\mathrm{mg} / \mathrm{kg} / \text { day })\end{array}$ & $\begin{array}{l}\text { Prednisone } \\
(\mathrm{mg} / \mathrm{kg} / \text { day })\end{array}$ & $\begin{array}{l}\text { Cyclosporine } \\
(\mathrm{mg} / \mathrm{kg} / \text { day })\end{array}$ & $\begin{array}{l}\text { Number of acute } \\
\text { rejection episodes }\end{array}$ \\
\hline TB - cured $(\mathrm{N}=22)$ & 1.63 & 0.41 & 5.19 & 1.60 \\
$\mathrm{~TB}-$ died $(\mathrm{N}=7)$ & 1.84 & $0.65^{*}$ & 6.17 & $2.33^{* *}$ \\
\hline
\end{tabular}

$* \mathrm{p}<0.05$ and $* * \mathrm{p}<0.001$ compared to the cured group. 


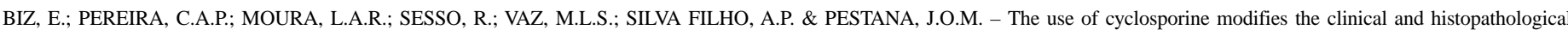
presentation of tuberculosis after renal transplantation. Rev. Inst. Med. trop. S. Paulo, 42(4): 225-230, 2000.

Pulmonary TB was the most common form of the disease and was diagnosed in $46 \%$ of our patients. QUINIBI et al. ${ }^{27}$, in a review of 77 cases, found pulmonary lesion in $40 \%$ of patients and the disseminated form of TB in $33 \%$. In a series from Southern India, pulmonary lesion occurred in $48 \%$, while $26 \%$ presented disseminated infection ${ }^{19,34}$. In the present study, simple radiologic examination of the thorax was abnormal in $86 \%$ of the patients with pleuropulmonary disease, with $46 \%$ presenting a miliary pattern. Mortality was lower when the disease was limited to the lung, and of the 7 patients who died, 5 had disseminated TB. Similar results have been reported in other studies ${ }^{35,37}$.

The initially employed therapeutic regimen for TB did not differ from that used for the general population, but great caution is recommended for the combined use of antituberculosis and immunosuppressive drugs due to the high possibility of hepatotoxicity $7,10,16,20$. The side effects of hepatotoxicity, gastric intolerance and peripheral neuritis led to discontinuation of treatment or to a change in the therapeutic scheme in 7 of 26 patients treated. Some authors avoid the use of rifampicin, even when serum cyclosporine levels are monitored ${ }^{1}$.

Only 2 of the 30 patients were submitted to chemoprophylaxis after transplantation. Chemoprophylaxis with isoniazid (300 mg/day) for 12 months is indicated in the following situations ${ }^{5,14}$ : patients living in an endemic area of TB and with a positive family history, patients with a previous history of inadequate treatment, patients presenting a PPD test of more than $10 \mathrm{~mm}$ in diameter and patients with pulmonary calcification, pleural thickening and hilar prominence upon chest X-ray.

The cases presented here illustrate the importance of the diagnosis of TB in post-transplant patients and its therapeutic difficulties. Fever was the most common initial symptom, with an earlier and predominantly extrapulmonary incidence being more common in patients receiving cyclosporine in combination with azathioprine and prednisone, compared to those who received the double immunosuppression regimen only. The histological granulomatous form predominated in the diagnosed cases after the first year of transplantation, while the exudative and mixed forms were mainly observed during the first year.

\section{RESUMO}

\section{O uso de ciclosporina modifica a apresentação clínica e histopatológica da tuberculose depois de transplante renal}

A tuberculose é uma das mais frequentes infecções oportunistas encontradas após o transplante renal. A tuberculose foi diagnosticada em 30 de 1.264 pacientes que foram transplantados entre 1976 e 1996 na unidade de Transplante Renal do Hospital São Paulo - UNIFESP e no Hospital Dom Silvério Gomes Pimenta em São Paulo. A incidência de $2,4 \%$, é cinco vezes superior à estimada para população geral brasileira. $\mathrm{O}$ diagnóstico foi realizado entre 50 dias a 18 anos após o transplante. Nos pacientes com esquema duplo de imunossupressão (prednisona e azatioprina), a manifestação inicial foi mais tardia, sendo que em 11 dos 13 pacientes ocorreu após os primeiros 3 anos de transplante. Enquanto com esquema tríplice (prednisona, azatioprina e ciclosporina), em 14 de 17 pacientes a doença ocorreu dentro dos primeiros 3 anos. Com esquema duplo de imunossupressão não houve manifestação de doença extra- torácica, em contrapartida com esquema tríplice de imunossupressão a forma de apresentação disseminada ocorreu em $35 \%$ dos casos, sendo mais precoce e mais grave. A febre foi o sintoma clínico principal em $90 \%$ dos casos. O diagnóstico foi confirmado, em $50 \%(\mathrm{n}=15)$ através da biópsia dos órgãos envolvidos, em $30 \%(\mathrm{n}=9)$ através da pesquisa de bacilos álcool ácido resistentes (BAAR) no escarro, em 7\% $(\mathrm{n}=2)$ no líquido céfaloraquidiano e em $13 \%(n=4)$ através de necrópsia. O tempo de tratamento da tuberculose variou de 6 a 13 meses. A hepatotoxidade relacionada ao tratamento, ocorreu em três casos. O número de tratamentos prévios de episódios de rejeição e a dose administrada de corticóides foram maiores nos pacientes que morreram com este diagnóstico, quando comparados ao grupo que respondeu ao tratamento. Em conclusão a forma clínica e histopatológica de apresentação da tuberculose é diferente após o transplante em pacientes utilizando ciclosporina, sendo a resposta ao tratamento influenciada pela dose prévia de corticóide.

\section{REFERENCES}

1. AGUADO, J.M.; HERRERO, J.A.; GAVALDÁ, J. et al. - Clinical presentation outcome of tuberculosis in kidney, liver, and heart transplant recipients in Spain. Transplantation, 63: 1278-1286, 1997.

2. AL-SULAIMAN, M.H.; DHAR, J.M.; AL-HASANI, M.K.; HALEEM, A. \& ALKHADER, A.A. - Tuberculous interstitial nephritis after kidney transplantation. Transplantation, 50: 162-164, 1990.

3. ANDREW, O. T.; SCHOENFELD, P. Y.; HOPEWELL, P.C. \& HUMPHREYS, M.H. Tuberculosis in patients with end-stage renal disease. Amer. J. Med., 68: 59-65, 1980.

4. CENGIZ, K. - Increased incidence of tuberculosis in patients undergoing hemodialysis. Nephron, 3: 421-424, 1996.

5. CHAVES, A.D.; CUGELL, D.W.; MARKS, C.E. et al. - Preventive treatment of tuberculosis. Amer. Rev. resp. Dis., 104: 460-465, 1971.

6. CRUZ, N.; MUXÓ, O.R.; BERMÚDEZ, R.H. \& DELPHIN, E.A.S. - Pulmonary infection with M. kansasii in a renal transplant patient. Nephron, 26: 187-188, 1980.

7. DI PERRI, G.; LUZZATI, R.; FORNI, A. et al. - Fatal primary multidrug-resistant tuberculosis in a heart transplant recipient. Transplant Int., 11: 305-307, 1998.

8. FORSLUND, T.; LAASONE, L.; HÖCKERSTEDT, K.; STENMAN, S. \& EDGREN, J. - Tuberculosis of the colon in a kidney transplant patient. Acta med. scand., 215: 181-184, 1984.

9. GOMEZ, E.; AGUADO, S.; BALTAR, J. et al. - Sterile leukocyturia as a manifestation of urinary tuberculosis in renal transplant patients. Nephrol. Dial. Tranplant., 13: 1610-1611, 1998.

10. HEBERT, M.F.; ROBERTS, J.P.; PRUEKSARITANONT, T. \& BENET, L.Z. Bioavailability of cyclosporine with concomitant rifampin administration is markedly less than predicted by hepatic enzyme induction. Clin. Pharmacol. Ther., 52: 453457, 1992.

11. HIGGINS, R.M.; CAHN, A.P.; PORTER, D. et al. - Mycobacterial infections after renal transplantation. Quart. J. Med., 286: 145-153, 1991.

12. JHA, V.; SAKHUJA, V.; GUPTA, D. et al. - Successful management of pulmonary tuberculosis in renal allograft recipients in a single center. Kidney Int., 56: 19441950, 1999.

13. JOHN, G.T.; VICENT, L.; JEYASEELAN, L.; JACOB, C.K. \& SHASTRY, J.C.M. Cyclosporine immunosuppression and Mycobacterium infections. Transplantation, 58: $247-248,1994$. 


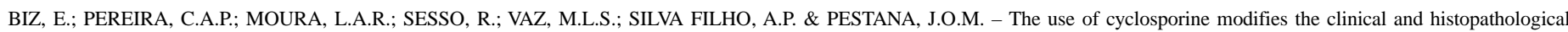
presentation of tuberculosis after renal transplantation. Rev. Inst. Med. trop. S. Paulo, 42(4): 225-230, 2000.

14. JORDAN, T.J.; LEWIT, E.M. \& REICHMAN, L.B. - Isoniazid preventive therapy for tuberculosis. Amer. Rev. resp. Dis., 144: 1357-1360, 1991.

15. KLEMPERER, J.D.; WANG, J.; HARTMAN, B.J. \& STUBENBORD, W.T. Mycobacterium tuberculosis infection of a native polycystic kidney following renal transplantation. Transplantation, 66: 118-120, 1998.

16. KOSELJ, M.; KANDUS, A. \& KOVAC, D. - Drug interactions between cyclosporine and rifampicin, erythromycin, and azoles in kidney recipients with opportunistic infections. Transplant. Proc., 26: 2823-2824, 1994.

17. LAKSHIMINARAYAN, S. \& SAHN, S.A. - Tuberculosis in a patient after renal transplantation. Tubercle (Edinb.), 54: 72-76, 1973.

18. LlOVERAS, J.; PETERSON, P.K.; SIMMONS, R.L. \& NAJARIAN, J.S. Mycobacterium infections in renal transplant recipients. Arch. intern. Med., 142: 888-892, 1982.

19. MALHOTRA, K.K.; DASH, S.C.; DHAWAN, I.K.; BHUYAN, U.N. \& GUPTA, A Tuberculosis and renal transplantation - observations from an endemic area of tuberculosis. Postgrad. med. J., 62: 359-362, 1986.

20. McALLISTER, W.A.C.; THOMPSON, P.J.; AL-HABET, S.M. \& ROGERS, H.J. Rifampicin reduces effectiveness and bioavailability of prednisolene. Brit. med. J., 286: 923-925, 1983.

21. MILLAR, J.W. \& HORNE, N.W. - Tuberculosis in immunosuppressed patients. Lancet, 2: 1176-1178, 1979.

22. MÜlLEROVA, M.; PEKAREK, J.; NOUZA, K. et al. - Immunosuppression and experimental tuberculosis. The effects of immunosuppressive agents and antilymphocyte serum on the organ dissemination of mycobacteria and on the development of specific delayed hypersensitivity. Biomedicine, 20: 390-397, 1974.

23. PARK, S.B.; JOO, I.; PARK, Y.I. et al. - Clinical manifestations of tuberculosis in renal transplant patients. Transplant. Proc., 28: 1520-1522, 1996.

24. PAULA, F.J.; AZEVEDO, L.S.F.; IANHEZ, L.E. et al. - Tuberculosis in patients with chronic renal failure. Rev. Inst. Med. trop. S. Paulo, 29: 127-130, 1987.

25. PAULA, F.J.; AZEVEDO, L.S.; SALDANHA, L.B.; IANHEZ, L.E. \& SABBAGA, E. Tuberculosis in renal transplant patients. Rev. Inst. Med. trop. S. Paulo, 29: 268$275,1987$.

26. PESCHKE, B.; ERNST, W.; GOSSMANN, J. et al. - Antituberculous drugs in kidney transplant recipients treated with cyclosporine. Transplantation, 56: 236-238, 1993.
27. QUINIBI, W.Y.; AL-SIBAI, M.B.; TAHER, S. et al. - Mycobacterial infections after renal transplantation-report of 14 cases and review of the literature. Quart. J. Med., 282: 1039-1060, 1990.

28. RISKA, H. \& KUHLBÄCK, B. - Tuberculosis and kidney transplantation. Acta med. scand., 205: 637-640, 1979.

29. RUBIN, R.H. - Infectious disease complications of renal transplantation. Kidney Int., 44: 221-236, 1993

30. SABBAGA, E. - 1.000 transplantes renais - vinte anos de experiência. São Paulo, 1987. (Tese de Livre-Docência - Faculdade de Medicina da Universidade de São Paulo).

31. SAHN, S.A. \& LAKSHMINARAYAN, S. - Tuberculosis after corticosteroid therapy Brit. J. Dis. Chest, 70: 195-205, 1976.

32. SAKHUJA, V.S.; JHA, V.; VARMA, P.P.; JOSHI, K. \& CHUGH, K.S. - The high incidence of tuberculosis among renal transplant recipients in India. Transplantation, 61: 211 215, 1996.

33. SHAHZAD, A.; SOOMRO, S. \& RIZVI, A. - Problems of diagnosis and treatment of tuberculosis following renal transplantation. Transplant. Proc., 29: 3051-3052, 1997.

34. SKOGBERG, K.; RUUTU, P.; TUKIAINEN, P. \& VALTONEN, V. - Effect of immunosuppressive therapy on the clinical presentation and outcome of tuberculosis. Clin. infect. Dis., 17: 1012-1017, 1993.

35. SPENCE, R.K.; DAFOE, D.C.; RABIN, G. et al. - Mycobacterium infections in renal allograft recipients. Arch. Surg., 118: 356-359, 1983.

36. STAKE, G. \& FLATMARK, A. - Lung complications during immunosuppressive treatment in renal transplant recipients. Scand. J. resp. Dis., 57: 51-62, 1976.

37. SUNDBERG, R.; SHAPIRO, R.; DARRAS, R. et al. - A tuberculosis outbreak in a renal transplant program. Transplant. Proc., 23: 3091-3092, 1991.

38. TATO, A.M.; PASCUAL, J.; OROFINO, L. et al. - Laryngeal tuberculosis in renal allograft patients. Amer. J. Kidney Dis., 31: 701-705, 1998.

39. WALKER, J.F.; CRONIN, C.J.; O'NEILL, S.; MCNULTY, J. \& HANSON, J.S. Tuberculosis affecting a cadaveric renal allograft. Clin. Nephrol., 17: 262-265, 1982.

40. WANG, A.Y.; LI, P.K.; TO, K.F.; LAI, F.M. \& LAI, K.N. - Coexistence of Kaposi's sarcoma and tuberculosis in a renal transplant recipient. Transplantation, 66: 115$118,1998$.

Received: 21 December 1999

Accepted: 17 March 2000 